Грищук О.К., Тімков О.М., Гладченко В.С.

Національний транспортний університет, Київ, Украйна

\title{
ПОШУК ПАРАМЕТРІВ СИЛОВОЇ УСТАНОВКИ ПЕРЕОБЛАДНАНОГО АВТОМОБІЛЯ
}

\begin{abstract}
Сьогодні зростає потреба у використанні колісних транспортних засобів (КТЗ) з нульовими викидами, частка таких КТЗ стрімко зростає в розвинених країнах. При цьому, існуючи звичайні автомобілі з ДВ3, мають значну кількість по всьому світу, створюють велику екологічну проблему. Одним з шляхів вирішення цієї проблеми $\epsilon$ їх переобладнання в гібридні або електричні КТЗ, які мають менший рівень викидів. В Україні дуже часто таке переобладнання роблять власники старих автомобілів, при цьому відсутні будь-які рекомендації, щодо його доцільності.

Відсутність методики розрахунку експлуатаційних властивостей переобладнаних КТЗ ускладнює цей процес, тому розробка такої методики $є$ актуальною задачею. Методика передбачає складання математичної моделі руху КТЗ з різними типами силових установок та різними компонувальними схемами. В роботі розглянута компонувальна схема гібридної силової установки (ГСУ) паралельного типу. Передня вісь приводиться в дію від ДВЗ, задня від електродвигуна (ЕД). Для складання рівнянь руху використана методика рівнянь Лагранжу. В якості узагальненої координати розглянуте кутове переміщення валу електродвигуна, до якого приведені параметри всіх механічних елементів КТЗ, у відповідності до його компонувальної схеми.

Проведено теоретичне дослідження енергетичних властивостей переобладнаного КТЗ в умовах руху м.Києва. За результатами обробки величини швидкості руху встановлений закон іiі розподілі та його параметри. Отримані данні були використані при розрахунках за запропонованою методикою та визначена величина швидкості для переходу на рух від ДВЗ та встановлений розподіл потужності між енергетичними елементами силової установки.

Ключові слова: гібридний автомобіль, електромобіль, переобладнання, ефективність, математична модель, силова установка, експеримент.
\end{abstract}

\section{ВСТУП}

Останнім часом питанню утилізації автомобілів, які відпрацювали свій термін служби приділяється велика увага. Старі автомобілі становлять небезпеку для навколишнього середовища, по-перше, це високий рівень забруднення повітря шкідливими речовинами, по-друге, мають недосконалі або взагалі відсутні системи активної та пасивної безпеки. Таким чином постає питання що з ними робити у перспективі [1].

Сьогодні спостерігається стрімке зростання популярності гібридних автомобілів та електромобілів [2,3], гучні заяви про заборону продажів звичайних автомобілів з ДВ3 в різних країнах Європи. Нові європейські плани щодо обмеження шкідливих викидів КТЗ, свідчать про закінчення епохи ДВЗ [4] як основного джерела енергії на КТЗ. Проте, сьогодні людство не готове повністю відмовитися від використання ДВ3, хоча така тенденція існує. Норми Євро 7, які повинні вступити в силу після 2025 року, встановлять юридичні обмеження для майже 100 мільйонів бензинових і дизельних автомобілів, що продаються в СС. У Європейській комісії вважають, що впровадження більш чистих технологій викидів для відповідності стандартам Євро-7 не є суттєвою проблемою для автовиробників, собівартість автомобіля зросте лише на $100-500$ євро, що не є занадто великою сумою.

За статистичними даними міністерства інфраструктури України [5] автомобільна транспортна система України налічує більш ніж 9,2 млн. транспортних засобів. Системи утилізації старих КТЗ в Україні немає. За період 2018 - 2020 років ситуація суттєво погіршилася внаслідок ввезення старих автомобілів з Європи, було зареєстровано понад 100 тис. автомобілів. Середній вік автомобілів складає 14 років, таким чином на сьогодні в Україні потребують утилізації вже понад 1 млн. автомобілів, що не придатні до експлуатації. Впровадження концепції утилізації таких автомобілів дасть можливість переробити їх не завдаючи шкоди навколишньому середовищу. Доцільність продовження використання системи капітального ремонту автомобілів яка існувала раніше, сьогодні викликає багато питань. Оскільки старі автомобілі не можуть конкурувати з новими за багатьма параметрами i в результаті ремонту не стають більш безпечними. На нашу думку, ремонт та подальше переобладнання в гібридний автомобіль або електромобіль $є$ більш доцільним. За наявними статистичними даними про кількість переобладнань в Україні [6] на підставі даних висновків науково-технічних експертиз зростає 3 кожним роком [7]. Тому ця робота присвячена саме переобладнанню автомобіля в гібридний. 


\section{АНАЛІЗ ЛІТЕРАТУРНИХ ДАНИХ ТА ПОСТАНОВКА ПРОБЛЕМИ}

Проблемами пов'язаними 3 розробкою та дослідженнями гібридних автомобілів та електромобілів, визначенням показників тягово-швидкісних властивостей, паливної та енергетичної ефективності присвячено багато робіт. Відомо багато робіт вітчизняних вчених: проф. Сахно В.П., доц. Поляков В.М., доц. Тімков О.М., проф. Клепіков В.Б., проф. Павлов В.Б, доц. Сітовскій О.П., доц. Дембицький В.М., проф. Двадненко В.Я., проф. Туренко А.М., проф. Гнатов А.В., проф. Богомолов В.А., проф. Абрамчук Ф.І., проф. Бажинов А.В. і багато інших вчених.

Огляд наукових робіт присвячених таким КТЗ показав, що використання математичних моделей для аналізу показників електричних КТЗ залишається надзвичайно високим. Кількісні показники, що одержують за допомогою аналітичних методів, є першими оцінками ефективності конструкції КТЗ, які надають уявлення про порядок та взаємозв'язок досліджуваних параметрів і про напрямок розвитку процесу. Точність таких оцінок не варто збільшувати за рахунок ускладнення аналітичного апарату - для точних розрахунків краще користуватися числовими методами 3 використанням ПК.

\section{ЦІЛЬ ТА ЗАДАЧІ ДОСЛІДЖЕННЯ}

Пошук співвідношення потужності джерел енергії гібридної силової установки переобладнаного автомобіля, яка б забезпечила виконання завданого швидкісного режиму руху та поліпшену паливну економічність, у порівнянні з звичайним автомобілем з ДВЗ.

\section{РЕЗУЛЬТАТИ ДОСЛІДЖЕНЬ}

Для переобладнання звичайного автомобіля 3 ДВЗ в гібридний 3 найменшими змінами конструкції найбільш підходить компонувальна схема середнього гібрида виконана за паралельною схемою. Єдиний механічний зв'язок між електричною системою та трансмісією КТЗ здійснюється через електродвигун. Компонування ГСУ визначається положенням електродвигуна та типом 3’єднання з трансмісією, Запропонована схема для переобладнання має ряд переваг:

- проста інтеграція в КТЗ;

- порівняно невелика вага компонентів, що незначно змінює повну масу;

- розумне співвідношення вартості та продуктивності системи (покращена паливна економічність, збільшений крутний момент).

Розглянемо структурну схему переобладнаного автомобіля що має ГСУ паралельного типу, рис. 1. На схемі наведені основні функціональні елементи, вхідні та вихідні сигнали кожного з них. Електродвигун передає крутний момент на задні колеса КТЗ, передні колеса приводяться в рух від ДВЗ, це дозволяє реалізувати режим руху з усіма ведучими колесами.

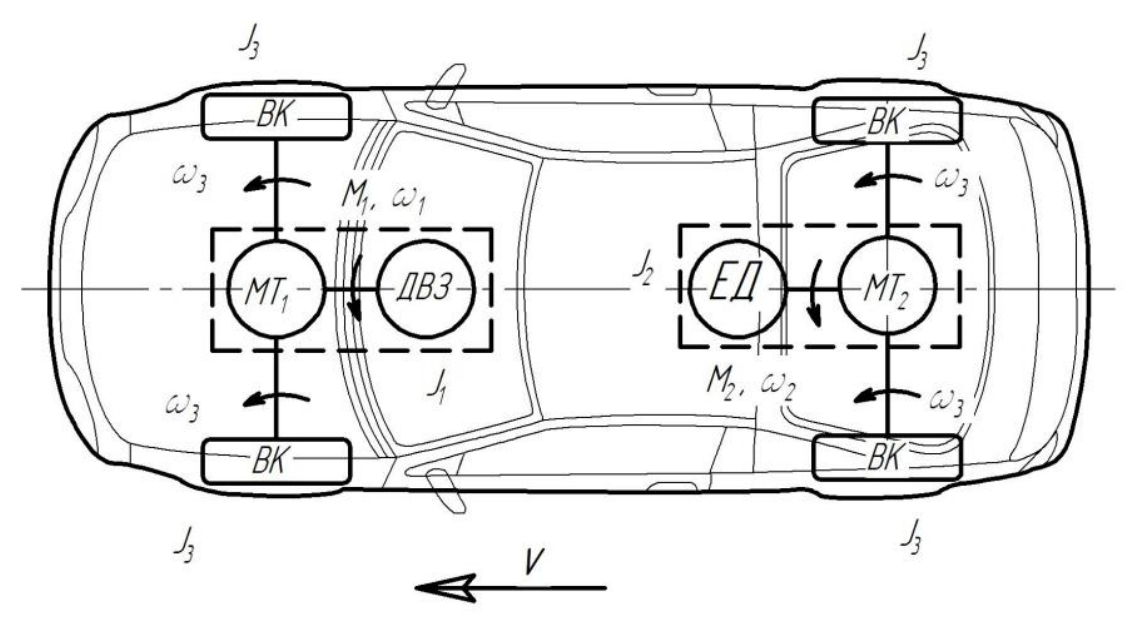

Рисунок 1 - Розрахункова компонувальна схема переобладнаного КТЗ

Основними функціональними елементами є: ДВЗ, механічна трансмісія приводу передніх коліс $\mathrm{MT}_{1}$, механічна трансмісія приводу задніх коліс $\mathrm{MT}_{2}$, ведучі колеса ВК. Робота системи характеризується такими параметрами як $M_{1}, \omega_{1}$ - крутний момент та кутова швидкість ДВ3, $M_{2}$, $\omega_{2}-$ крутний момент та кутова швидкість ЕД, $\omega_{3}-$ кутова швидкість ведучих коліс, $J_{1}, J_{2}, J_{3}-$ відповідно моменти інерції ДВЗ, ЕД та ВК.

Для математичного опису динамічних процесів що відбуваються в механічній частині електроприводу використані рівняння Лагранжу в узагальнених координатах $[8,9]$ : 


$$
\frac{\mathrm{d}}{\mathrm{dt}}\left(\frac{\partial \mathrm{E}_{\mathrm{k}}}{\partial \dot{\mathrm{q}}_{\mathrm{i}}}\right)-\frac{\partial \mathrm{E}_{\mathrm{k}}}{\partial \mathrm{q}_{\mathrm{i}}}=\mathrm{Q}_{\mathrm{i}}
$$

де: $E_{k}-$ накопичена кінетична енергія системи, визначена через узагальнені координати $q_{i}$ and та узагальнені швидкості $\dot{q}_{i}$;

$Q_{i}=\partial A_{i} / \partial q_{i}-$ узагальнена сила, обумовлена сумою елементарних робіт $\partial A_{i}$ всіх діючих сил на можливому переміщенні $\partial q_{i}$.

В якості узагальненої координати $q_{i}$ в електроприводі, як правило, приймають кутове переміщення $\varphi$ вала ЕД, до якого приводяться параметри всіх механічних ланок системи $[8,9]$. Розглядаючи механічну систему переобладнаного КТЗ з одним ступенем вільності та узагальненою координатою - кутом $\varphi$, повороту вала електроприводу рівняння (2) запишемо у вигляді:

$$
\frac{\mathrm{d}}{\mathrm{dt}}\left(\frac{\partial \mathrm{E}_{\mathrm{k}}}{\partial \dot{\varphi}_{\mathrm{i}}}\right)-\frac{\partial \mathrm{E}_{\mathrm{k}}}{\partial \varphi_{\mathrm{i}}}=\mathrm{Q}_{\mathrm{i}}
$$

де : $E_{k}-$ накопичена кінетична енергія гібридного КТЗ;

$\dot{\varphi}-$ кутова швидкість вала тягового електродвигуна;

$Q$ - узагальнена сила, що діє на переміщенні $\varphi$.

На підставі обраної компонувальної схеми, складена узагальнена розрахункова механічна схема переобладнаного гібридного КТЗ. Отримаємо рівняння руху, відповідно до розрахункової схеми на рис. 1. Запас кінетичної енергії гібридного КТЗ $E_{k}$ визначається сумою кінетичних енергій ДВЗ та ЕД з трансмісіями, відповідно $E_{1}$ та $E_{2}$, кузова автомобіля з вантажем $E_{0}$ та чотирьох ведучих коліс $4 E_{3}$ :

$$
E_{k}=E_{0}+E_{1}+E_{2}+4 E_{3}
$$

Розкриємо значення кінетичної енергії для кожного з елементів рівняння (4), одержимо:

$$
\mathrm{E}_{\mathrm{k}}=\frac{1}{2}\left(\left(\mathrm{~m}_{0}+\mathrm{m}_{1}+\mathrm{m}_{2}+4 \mathrm{~m}_{3}\right) \mathrm{v}^{2}+\mathrm{J}_{1} \omega_{1}^{2}+\mathrm{J}_{2} \omega_{2}^{2}+4 \mathrm{~J}_{3} \omega_{3}^{2}\right) \text {, }
$$

де: $m_{0}, m_{1}, m_{2}, m_{3}-$ відповідно, маса кузова КТЗ з вантажем, маса ДВЗ, ЕД з трансмісіями та маса колеса;

$v$ - лінійна швидкість КТЗ;

$\omega_{1}, \omega_{2}, \omega_{3}-$ кутова швидкість валу ДВЗ, ЕД та колеса, відповідно;

$J_{1}, J_{2}, J_{3}-$ моменти інерції ДВЗ, ЕД з трансмісіями та колеса, відповідно.

Враховуючи, що передаточне відношення трансмісії $\mathrm{MT}_{1}$ від ДВЗ визначається як $U_{1}=\omega_{1} / \omega_{3}$, та $\mathrm{MT}_{2}$ для електроприводу як $U_{2}=\omega_{2} / \omega_{3}$ тоді лінійна швидкість КТЗ з гібридною силовою установкою складатиме $v=\omega_{3} R$, вираз (5) перетворимо до вигляду:

$$
E_{k}=\frac{1}{2}\left(\left(m_{0}+m_{1}+m_{2}+4 m_{3}\right) \frac{R^{2}}{U_{1}^{2}}+J_{1}+J_{2} \frac{U_{2}}{U_{1}}+4 \frac{J_{3}}{U_{1}^{2}}\right) \omega_{1}{ }^{2}=\frac{1}{2} J_{\Sigma} \dot{\varphi}_{1}^{2},
$$

де: $R$ - радіус колеса КТЗ;

$\omega_{1}=\frac{d \varphi_{1}}{d t}=\dot{\varphi}_{1}-$ кутова швидкість валу ДВ3;

$\omega_{2}=\frac{d \varphi_{2}}{d t}=\dot{\varphi}_{2}-$ кутова швидкість валу ЕД;

$J_{\Sigma}=\left(m_{0}+m_{1}+m_{2}+4 m_{3}\right) \frac{R^{2}}{U_{1}^{2}}+J_{1}+J_{2} \frac{U_{2}}{U_{1}}+4 \frac{J_{3}}{U_{1}^{2}} \quad$ сумарний момент інерції приведений до валу тягового електродвигуна/ДВЗ КТЗ з ГСУ.

Під час руху переобладнаного КТЗ на нього діють сили опору [10, 11], до яких належить сила опору повітря $F_{w}$, сила сумарного опору дороги, вона складається з сили опору кочення - сила $F_{f}$ та підйому $-F_{\psi}$. Схема діючих сил у загальному випадку наведена на рис. 2 . 


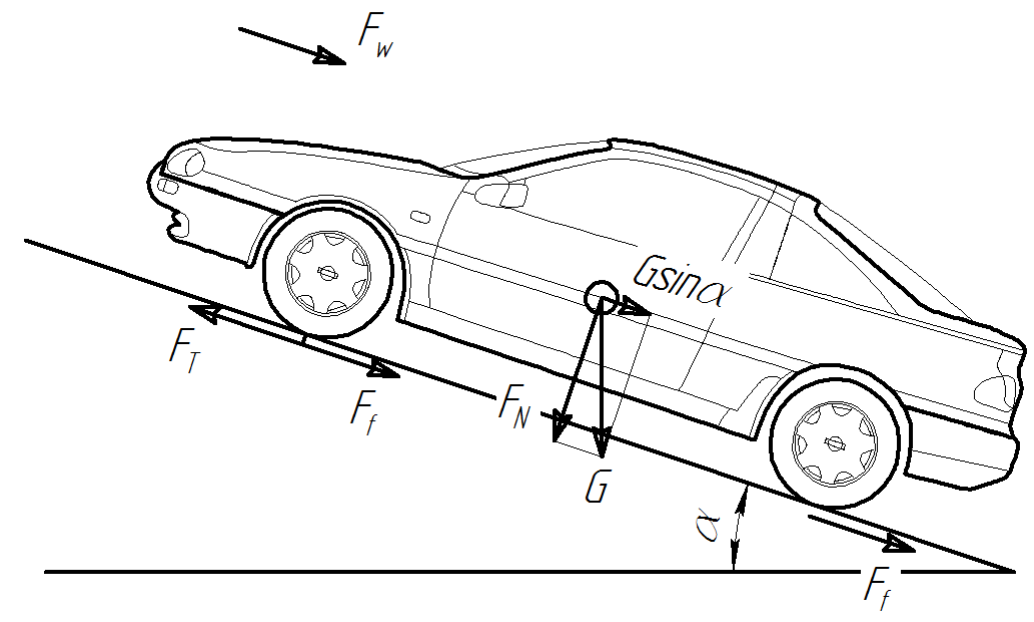

Рисунок 2 - Схема сил, що діють на КТЗ у загальному випадку

Для визначення узагальненої сили $Q$ необхідно обчислити елементарну роботу всіх моментів, що діють на КТЗ під час його руху, на елементарному переміщенні $\partial \varphi$ :

$$
\partial \mathrm{A}=\left(\mathrm{M}_{1}+\mathrm{M}_{2}-\mathrm{M}_{\mathrm{f}}-\mathrm{M}_{\mathrm{w}} \mp \mathrm{M}_{\psi}-\mathrm{M}_{\eta}\right) \partial \varphi,
$$

де: $M_{1}-$ крутний момент, що створює ДВ3, $M_{1}=f\left(\omega_{1}\right)$;

$M_{2}$ - крутний момент, що створює ЕД, $M_{2}=f\left(\omega_{2}\right)$;

$M_{f}$ - момент сил опору коченню КТЗ, приведений до валу ДВЗ та ЕД;

$M_{w}-$ момент сил опору повітря КТЗ, приведений до валу ДВЗ та ЕД;

$M_{\psi}$ - момент сил опору підйому/спуску КТЗ, приведений до валу ДВЗ та ЕД;

$M_{\eta}$ - момент сил, що враховує втрати в механізмах трансмісії КТЗ, приведений до валу ДВЗ та ЕД.

Виходячи з рівняння (7), одержимо:

$$
\mathrm{Q}=\frac{\partial \mathrm{A}}{\partial \varphi}=\mathrm{M}_{1}+\mathrm{M}_{2}-\mathrm{M}_{\mathrm{f}}-\mathrm{M}_{\mathrm{w}} \mp \mathrm{M}_{\psi}-\mathrm{M}_{\eta}
$$

Підставимо рівняння (6) та (8) до (3), продиференціюємо його, одержимо рівняння руху переобладнаного КТЗ з гібридною силовою установкою:

$$
\mathrm{M}_{1}+\mathrm{M}_{2}-\mathrm{M}_{\mathrm{f}}-\mathrm{M}_{\mathrm{w}} \mp \mathrm{M}_{\Psi}-\mathrm{M}_{\eta}=\mathrm{J}_{\Sigma} \ddot{\varphi}=\mathrm{J}_{\Sigma} \frac{\mathrm{d} \omega}{\mathrm{dt}} .
$$

Визначимо моменти, що діють на КТЗ під час його руху $[10,11]$. Момент сили опору кочення коліс, приведений до валу ГСУ:

$$
M_{f}=\frac{1}{U_{1}} F_{N} f=\frac{1}{U_{1}} G f \cos \alpha=\frac{1}{U_{1}} f g\left(m_{0}+m_{1}+m_{2}+4 m_{3}\right),
$$

де: $F_{N}-$ нормальна складова сили тяжіння КТЗ;

$\alpha-$ в кут нахилу дороги;

$g$ - прискорення вільного падіння;

$f-$ коефіцієнт опору кочення дороги.

Момент сил опору повітря КТЗ, приведений до валу ДВ3 можна визначити за формулою: 


$$
M_{w}=\frac{1}{2} \rho C_{d} A_{e} v^{2} \frac{R}{U_{1}}=\frac{1}{2} \rho C_{d} A_{e}\left(\frac{R}{U_{1}}\right)^{3} \omega_{1}^{2}
$$

де: $\rho$ - густина повітря за нормальних умов;

$C_{d}-$ коефіцієнт аеродинамічного опору кузова КТЗ;

$A_{e}$ - лобова площа КТЗ.

Момент сил опору підйому/спуску КТЗ, приведений до валу силової установки:

$$
\mathrm{M}_{\Psi}=\mathrm{G} \frac{\mathrm{R}}{\mathrm{U}_{1}} \sin \alpha
$$

Момент сил, що враховує втрати в механізмах трансмісії КТЗ, приведений до валу ГСУ:

$$
M_{\eta}=\left(1-\eta_{\Sigma}\right) M
$$
енергіï.

де: $\eta_{\Sigma}-$ сумарний ККД механічної передачі, ДВЗ, електричних машин та перетворювачів ГСУ:

Підставимо рівняння (10..13) до виразу (9), одержимо рівняння руху переобладнаного КТЗ 3

$$
M \eta_{\Sigma}-F_{N} \frac{f}{U_{1}}-\frac{1}{2} \rho C_{d} A_{e}\left(\frac{R}{U_{1}}\right)^{3} \omega_{1}^{2} \mp G \frac{R}{U_{1}} \sin \alpha=J_{\Sigma} \frac{d \omega}{d t}
$$

\section{ОБГОВОРЕННЯ РЕЗУЛЬТАТІВ ДОСЛІДЖЕННЯ}

Для проведення числового експерименту з використанням ПК, було обрано наступні вихідні данні, що відповідають типовому легковому автомобілю категорії М1, див. табл. 1.

Таблиця 1 - Вихідні данні для моделювання руху переобладнаного КТЗ

\begin{tabular}{|l|c|c|}
\hline Параметр & Значення & Одиниця виміру \\
\hline Маса КТ3 & 1110 & кг \\
\hline Коефіцієнт аеродинамічного опору & 0.29 & - \\
\hline Лобова площа КТ3 & 1.86 & м $^{2}$ \\
\hline База КТ3 & 2320 & мм \\
\hline Відстань від передньої осі до центру мас КТ3 & 939 & мм \\
\hline Відстань від задньої осі до центру мас КТ3 & 1380 & мм \\
\hline Передаточне відношення коробки передач, & 3.454 & \\
відповідно: & 2.056 & \\
\hline Дередаточ'не число головної передачі & 1.333 & \\
\hline Динамічний радіус колеса & 0.969 & - \\
\hline
\end{tabular}

Кафедрою «Автомобілі» Національного транспортного університету (НТУ), було проведено дослідження реальних швидкісних режимів руху автомобілів в умовах м. Києва [12]. За результатами статистичної обробки даних встановлено, що середня швидкість руху знаходиться у межах $23 . .25$ км/год. Експлуатаційний маршрут передбачав рух центральною частиною міста та так званими «спальними» районами, що є характерним для міських агломерацій. У якості прикладу на рис. 3 наведена залежність швидкості руху на експлуатаційному маршруті від часу. 


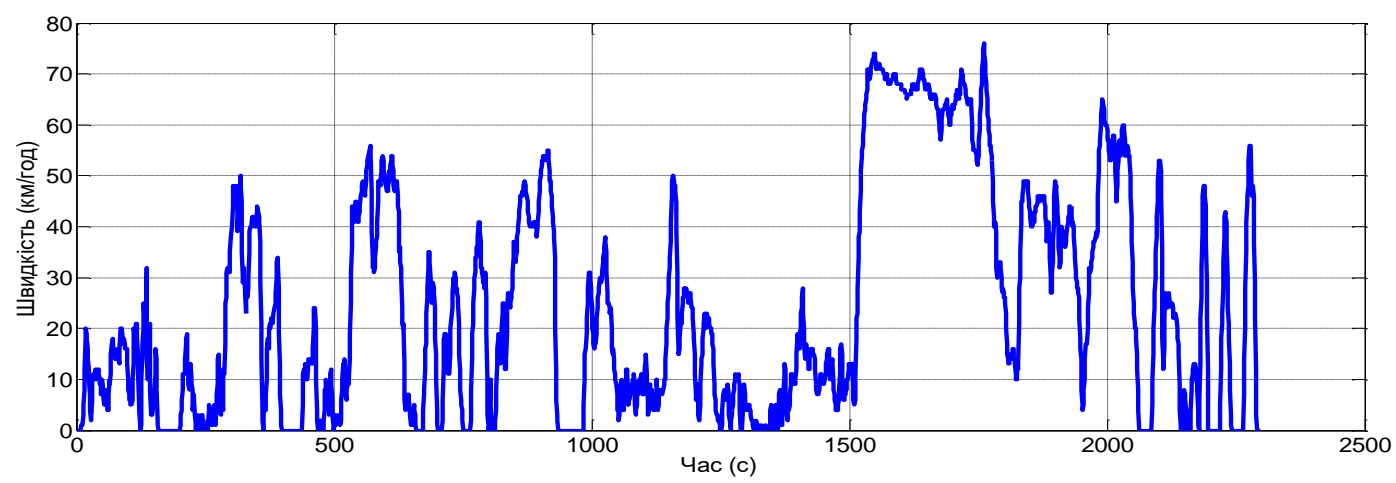

Рисунок 3 - Швидкість руху на експлуатаційному маршруті в м. Києві

На основі отриманих даних розподілу швидкості руху на експлуатаційному маршруті руху в м. Києві в процесі моделювання за розробленою моделлю було проведено обгрунтування вибору граничного значення швидкості руху, до якої працює тільки електродвигун, визначено розподіл потужності між ДВЗ та ЕД.

В якості прикладу на рис. 4...6 наведені графічні залежності результатів розрахунків, отримані витрата палива, потужність ДВЗ, потужність ЕД та інші.

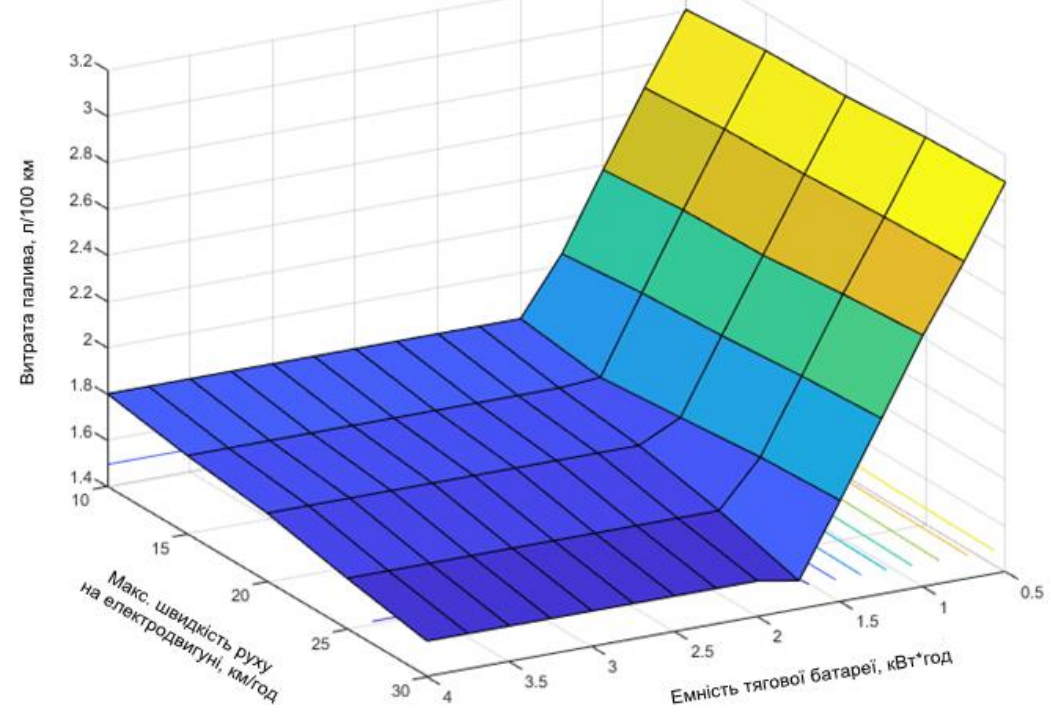

Рисунок 4 - Витрата палива переобладнаного КТЗ з ГСУ

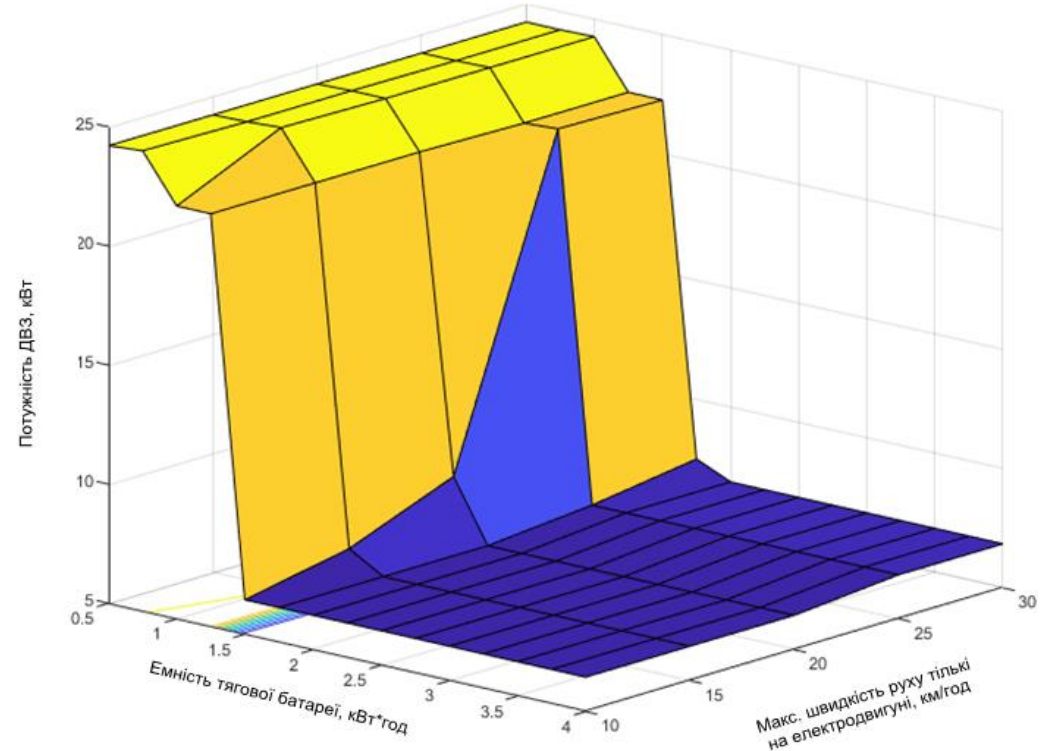

Рисунок 5 - Розподіл потужності ДВЗ переобладнаного КТЗ з ГСУ 


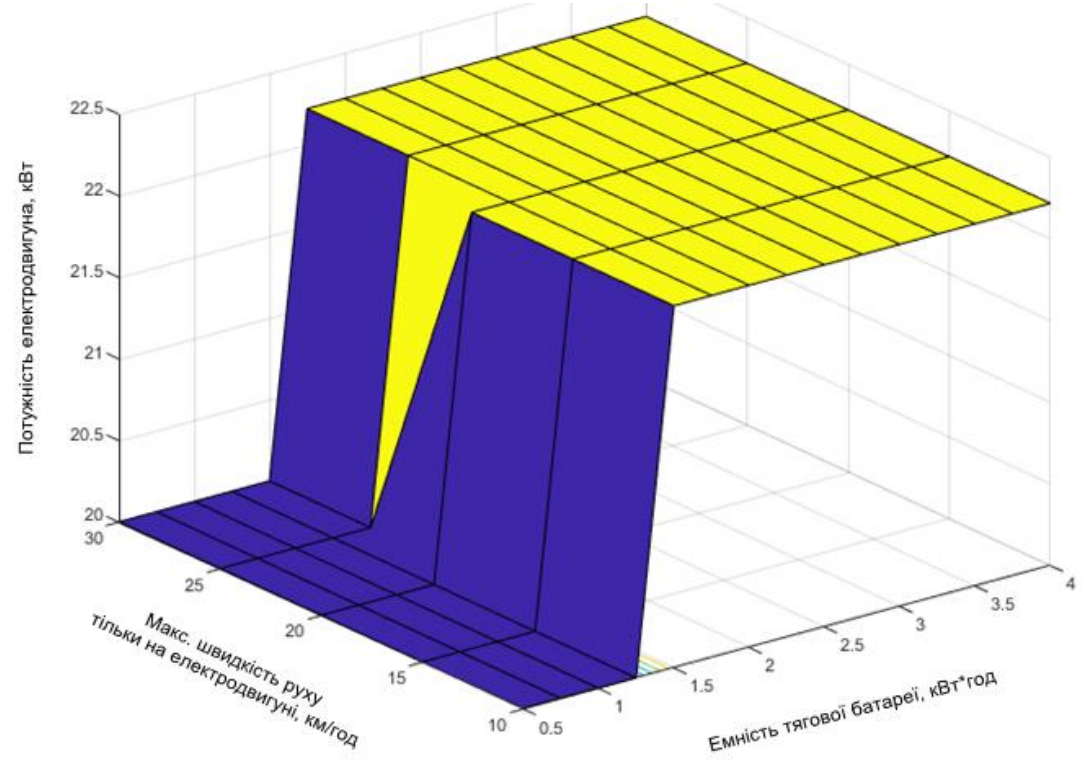

Рисунок 6 - Розподіл потужності ЕД переобладнаного КТЗ з ГСУ

Істотною відмінністю множин параметрів ГСУ є величина енергії, необхідна для виконання завданого швидкісного режиму руху на маршруті. Навіть незначне підвищення швидкості руху тільки на ЕД дозволяе істотно зменшити витрату палива ДВЗ. Встановлено, що максимальна потужність ГСУ використовується в експлуатаційному маршруті руху лише $2 \%$ від загального часу руху на маршруті. На рис. 7 , наведений графік кумулятивної функції розподілу використання потужності ЕД.

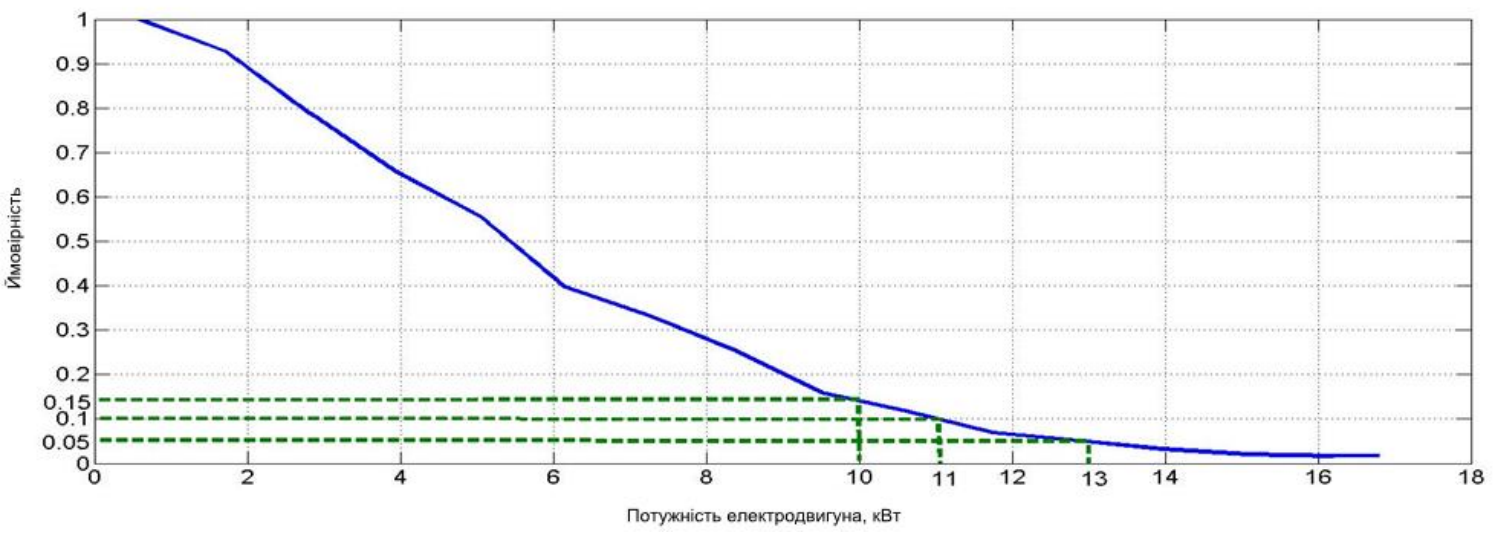

Рисунок 7 - Кумулятивна функція розподілу використання потужності ЕД

3 метою підвищення ступеня використання потужності ДВЗ розглянемо можливість зниження потужності ГСУ, при якому вона буде використовуватися 3 ймовірністю 0,95, 0,90 та 0,85, 3 наступною перевіркою тягово-швидкісних та енергетичних властивостей. Такий підхід дозволяє знизити вартість ГСУ.

Аналіз гістограми розподілу потрібної потужності ЕД в залежності від швидкості руху, рис. 8 показує, що при спільній роботі ЕД та ДВЗ в усьому швидкісному діапазоні, зниження потужності ГСУ призводить до неможливості виконання швидкісного режиму руху на маршруті.

Остаточне обгрунтування величини потужності ГСУ та її розподіл між ЕД та ДВЗ відбувається в процесі моделювання за математичною моделлю, за умови виконання швидкісного режиму як на експлуатаційному маршруті так і в новому європейському їздовому циклі. 


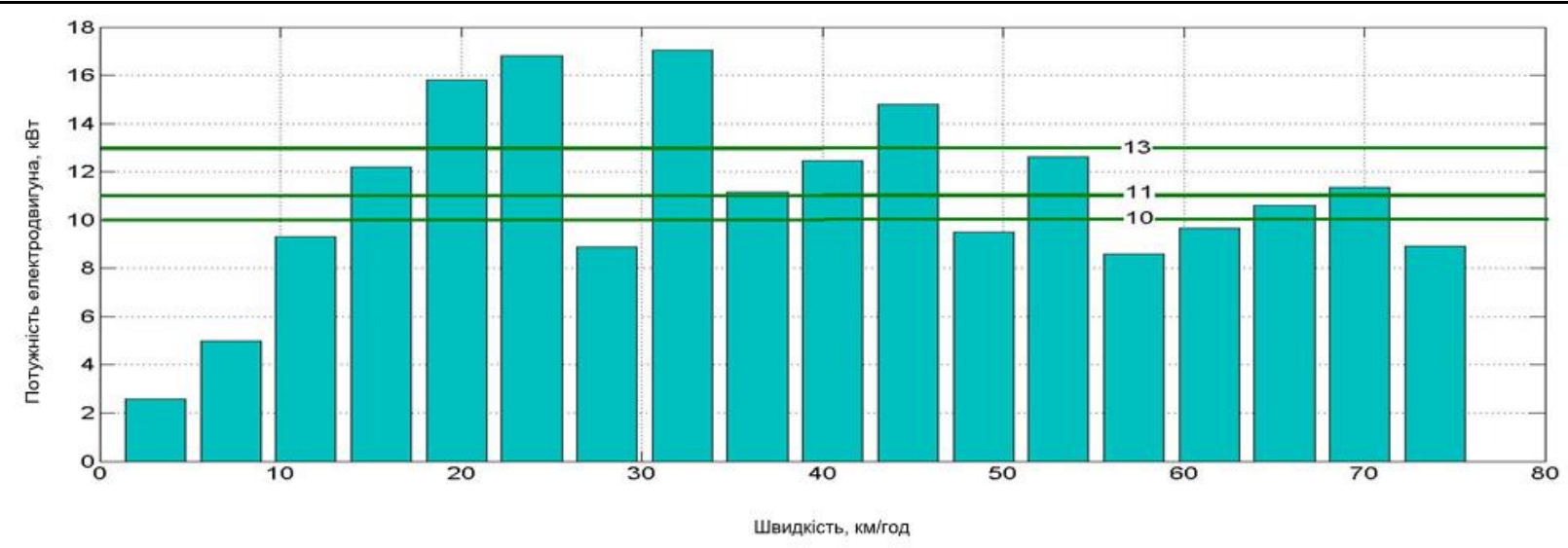

Рисунок 8 - Гістограма розподілу потрібної потужності ЕД

Встановлено, що для забезпечення можливості виконання швидкісного режиму руху, існує множина співвідношень потужностей елементів ГСУ. Так, потрібна потужність ЕД знаходиться в межах від 16,8 кВт до 30 кВт, що становить 44,2...78,9 \% від повної потужності ГСУ. Потужність ДВ3 складає від 21,2 до 8 кВт. При цьому, витрата електричної енергії батареї становитиме 3,1 ...4,9 МДж/цикл, а витрата енергії палива складатиме 7,5...3 МДж/цикл. Використання зазначених множин співвідношень потужності ДВЗ та ЕД дозволяе виконати швидкісні умови експлуатаційного режиму руху, але постає питання обгрунтування вибору остаточного значення потужності ЕД та ДВЗ.

\section{ВИСНОВКИ}

1. Проблема утилізації старих транспортних засобів $є$ надзвичайно актуальною для України. Середній вік транспортних засобів перевищує 6 років, та внаслідок лібералізації законодавства останніми роками, цей показник збільшився майже вдвічі до 13! Системи утилізації автомобілів в Україні немає.

2. Одним з шляхів вирішення цієї проблеми є переобладнання серійного автомобіля з ДВЗ в електромобіль чи гібридний автомобіль. У серійному автомобілі вже існують всі вузли трансмісії для підключення ЕД. Залишається лише виготовити перехідні елементи для з'єднання валів двигуна та КП, а також для кріплення ЕД, акумуляторів та елементів управління до кузова автомобіля. Наразі характеристики ЕМ більш придатні для його внутрішньо міського використання (з обмеженою максимальною швидкістю та пробігом при порівняно гарній якості доріг), і це дає змогу знизити певні вимоги до деяких конструктивних характеристик КТЗ, який переобладнується.

3. Отримані математичні рівняння руху переобладнаного автомобіля з ГСУ. Вони дозволяють визначити експлуатаційні показники переобладнаних легкових автомобілів категорії М1 на етапі розробки проекту з переобладнання, обрати найбільш оптимальний варіант та схему переобладнання.

4. В роботі запропоновано прийняти у якості граничного значення швидкості, до якої працює ЕД, значення математичного очікування середньої швидкості руху на експлуатаційному маршруті в м. Києві - 24,2 км/год. Це є вихідним значенням для вибору інших параметрів ГСУ. Для подальшого аналізу приймаються наступні параметри ГСУ: максимальна швидкість руху тільки на ЕД - 24,2 км/год; потужність ЕД - 16,8 кВт; потужність ДВ3 - 21,2 кВт (співвідношення 44/56\%).

\section{ПЕРЕЛІК ДЖЕРЕЛ ПОСИЛАННЯ}

1.Hujo, L. \& Jablonický, J. \& Tkáč, Z. \& Angelovič, M. \& Rečková, B. Assessment of a Transport Company in Terms of Performance Utilisation of Vehicles, Acta Technologica Agriculturae. 2013. Vol. 16(1), No. 1-4. DOI: https://doi.org/10.2478/ata-2013-0001.

2.Toyota Mirai. Вікіпедія. 2021. [Electronic resource] // URL: https://uk.wikipedia.org/wiki/Toyota_Mirai (accessed: 15.02.2021).

3.Larminie J., Lowry J. Electric Vehicle Technology Explained, 2nd Edition / Wiley. John Wiley \& Sons, 2003.

4.Когда мир попрощается с автомобилями с ДВС: Авто новости от AUTO-Consulting - ДВС [Electronic resource]. URL: https://www.autoconsulting.com.ua/article.php?sid=49689 (accessed: 04.10.2021).

5.Міністерство інфраструктури України [online] [цит. 03.08.2021]. Режим доступу: http://mtu.gov.ua/. 
6.Грищук О.К. Щодо переобладнання автомобіля на електромобіль / О.К. Грищук, В.С. Гладченко, Ю.М. Оверченко // Автошляховик України, Автомобільний транспорт №4, - 2019, С.2935. DOI: 10.33868/0365-8392-2019-4-260-29-35.

7.Транспортна стратегія України на період до 2020 року. 2009, 36 с. [online] [cit. 24.01.2020]. Режим доступу: https://www.insat.org.ua/files/anons/2_dod_3.doc.

8.Childs, Dara W. Conkey, Andrew P Dynamics in engineering practice, 11 edition. CRC Press. Taylor \& Francis Group. 2015. 209 pp. ISBN 978-1-4822-5025-1.

9.Sapio, V. Advanced Analytical Dynamics. Theory and Applications. Cambridge University Press. 2017. 305 pp. ISBN 978-1-107-17960-8.

10.Сахно В.П. Автомобілі: Тягово-швидкісні властивості та паливна економічність / В.П. Сахно, Г.Б. Безбородова, М.М. Маяк, С.М. Шарай// Навч. посібник/. -К.: В-во «КВІЦ», 2004, 174 с., іл. 15 , т. 9, бібл. 30 .

11.Pacejka, H. Tire and Vehicle Dynamics. (3rd Edition). Butterworth-Heinemann, Elsevier, 2012. 672 p. ISBN 978-0-0809-7016-5.

12.Сахно В. П. Методика визначення характеристик агрегатів ГСУ та режимів їх роботи для вантажних автомобілів в залежності від умов експлуатації / В. П. Сахно, В. М. Поляков, О. М. Тімков, О.С. Іванов // Вісник Національного технічного університету "ХПІ". Серія : Математичне моделювання в техніці та технологіях. - 2015. - № 6. - С. 137-147. - Режим доступу: http://nbuv.gov.ua/UJRN/vcpimm_2015_6_20.

\section{REFERENCES}

1.Hujo, L. \& Jablonický, J. \& Tkáč, Z. \& Angelovič, M. \& Rečková, B. Assessment of a Transport Company in Terms of Performance Utilisation of Vehicles, Acta Technologica Agriculturae. 2013. Vol. 16(1), No. 1-4. DOI: https://doi.org/10.2478/ata-2013-0001.

2.Toyota Mirai. Вікіпедія. 2021. [Electronic resource] // URL: https://uk.wikipedia.org/wiki/Toyota_Mirai (accessed: 15.02.2021).

3.Larminie J., Lowry J. Electric Vehicle Technology Explained, 2nd Edition / Wiley. John Wiley \& Sons, 2003.

4.When the world says goodbye to ICE cars: Auto news from AUTO-Consulting - ICE [Electronic resource]. URL: https://www.autoconsulting.com.ua/article.php?sid=49689 (accessed: 04.10.2021).

5.Ministry of Infrastructure [online] [cit. 03.08.2021]. Available on the Internet: http://mtu.gov.ua.

6. Gryshchuk O.K. Converting the vehicle by replacing the internal combustion engine / O.K. Gryshchuk, V.S. Hladchenko, Yu.M. Overchenko // Motorway of Ukraine, Road transport №4, - 2019, C.29-35. DOI: 10.33868/0365-8392-2019-4-260-29-35.

7.Transport strategy of Ukraine for the period up to 2020. 2009, 36 p. [online] [cit. 24.08.2021]. Available on the Internet: https://www.insat.org.ua/files/anons/2__dod_3.doc.

8.Childs, Dara W. Conkey, Andrew P Dynamics in engineering practice, 11 edition. CRC Press. Taylor \& Francis Group. 2015. 209 pp. ISBN 978-1-4822-5025-1.

9.Sapio, V. Advanced Analytical Dynamics. Theory and Applications. Cambridge University Press. 2017. 305 pp. ISBN 978-1-107-17960-8.

10.Sakhno, V.P., Bezborodova, H.B., Mayak, M.M., Sharay, S.M., (2004) Cars: Traction-speed properties and fuel economy. Educ. manual/. - K .: In "KVITs", 174 p., Fig. 15, Vol. 9, Bibl. 30.

11.Pacejka, H. Tire and Vehicle Dynamics. (3rd Edition). Butterworth-Heinemann, Elsevier, 2012. 672 p. ISBN 978-0-0809-7016-5.

12.Sakhno V.P. Method of determining the characteristics of HEV units and their modes of operation for trucks depending on operating conditions / V.P. Sakhno, V.M. Polyakov, O.M. Timkov, O.S. Ivanov // Bulletin of the National Technical University "KhPI". Series: Mathematical modeling in engineering and technology. - 2015. - № 6. $\quad$ - C. 137-147. $\quad$ - [Electronic resource]: http://nbuv.gov.ua/UJRN/vcpimm_2015_6_20.

\section{Gryshchuk O., Timkov O., Hladchenko V. Search for parameters of the power plant of the re- equipped vehicles}

Nowadays, the need to use wheeled vehicles with zero emissions, the share of such vehicles is growing rapidly in developed countries. At the same time, existing re-equipped vehicle with internal combustion engines, have a significant number around the world, create a major environmental problem. One way to overcome this problem is to convert them into hybrid or electric vehicles with lower emissions. 
In Ukraine, such re-equipment is very often done by owners of old vehicles, and there are no recommendations on its feasibility.

The lack of a method for calculating the performance of re-equipped vehicles complicates this process, so the development of such a method is an urgent task. The method involves compiling a mathematical model of the movement of vehicles with different types of power plants and different layout schemes. The layout scheme of a hybrid power plant of parallel type is considered in this article. The front axle is driven by the internal combustion engine, the rear by the motor. The method of Lagrange equations was used to compile the equations of motion. As a generalized coordinate, the angular displacement of the motor shaft is considered, to which the parameters of all mechanical elements of the vehicle are given, in accordance with its layout.

Theoretical research of energy properties of the re-equipped vehicle in the conditions of movement of Kyiv is carried out. According to the results of processing the value of the speed of movement, the law of its distribution and its parameters are established. The obtained data were used in the calculations according to the proposed method and the value of the speed for the transition to the movement of the internal combustion engine was determined and the power distribution between the power elements of the power plant was established.

Key words: hybrid vehicles, electromobile, re-equipped, efficiency, mathematical model, power plant, experiment.

ГРИЩУК Олександр Казимирович, кандидат технічних наук, професор, Національний транспортний університет, e-mail: gryshchuk@ntu.edu.ua, orsid.org/0000-0003-2993-5566.

ТІМКОВ Олексій Миколайович, доцент, к.т.н., доцент кафедри автомобілів Національного транспортного університету, e-mail: alextimkov@ gmail.com, https://orcid.org/0000-0002-7925-7030.

ГЛАДЧЕНКО Володимир Сергійович, аспірант кафедри туризму, Національний транспортний університет, e-mail: v.glad4enko@ukr.net, https://orcid.org/0000-0001-5783-4880.

Oleksandr GRYSHCHUK, Professor, PhD, National Transport University, e-mail: gryshchuk@ntu.edu.ua, https://orsid.org/0000-0003-2993-5566.

Oleksii TIMKOV, Associate professor, $\mathrm{PhD}$, Department of Automobiles National Transport University, e-mail: alextimkov@gmail.com, https://orcid.org/0000-0002-7925-7030.

Volodimir HLADCHENKO, graduate student of the Department of Tourism the National Transport University, e-mail: v.glad4enko@ukr.net, https://orcid.org/0000-0001-5783-4880.

DOI 10.36910/automash.v2i17.636 